\title{
Usher Syndrome
}

National Cancer Institute

\section{Source}

National Cancer Institute. Usher Syndrome. NCI Thesaurus. Code C85217.

A rare, autosomal recessive inherited syndrome caused by mutations in the $\mathrm{CDH} 23$,

CLRN1, GPR98, MYO7A, PCDH15, USH1C, USH1G, and USH2A genes. It is characterized by hearing loss or deafness and progressive loss of vision. The loss of vision is the result of retinitis pigmentosa. 